\title{
Readymade Solutions and Students' Appetite for Plagiarism as Challenges for Online Learning
}

\author{
Daniela Sorea *, Gheorghe Roșculeț and Ana-Maria Bolborici \\ Department of Social and Communication Sciences, Transilvania University of Brașov, 29, Eroilor Bd., \\ 500036 Brașov, Romania; grosculet@unitbv.ro (G.R.); ana.bolborici@unitbv.ro (A.-M.B.) \\ * Correspondence: sorea.daniela@unitbv.ro
}

Citation: Sorea, D.; Roșculeț, G.; Bolborici, A-M. Readymade Solutions and Students' Appetite for Plagiarism as Challenges for Online Learning. Sustainability 2021, 13, 3861. https://doi.org/10.3390/su13073861

Academic Editor: Marc Alier

Received: 27 February 2021

Accepted: 26 March 2021

Published: 31 March 2021

Publisher's Note: MDPI stays neutral with regard to jurisdictional claims in published maps and institutional affiliations.

Copyright: (c) 2021 by the authors. Licensee MDPI, Basel, Switzerland. This article is an open access article distributed under the terms and conditions of the Creative Commons Attribution (CC BY) license (https:/ / creativecommons.org/licenses/by/ $4.0 /)$.

\begin{abstract}
In the context of the COVID-19 pandemic, the importance of online learning has increased. Inherently, the stakes of a sustainable approach to the challenges raised by the wide access to the Internet, the use of readymade solutions to meet didactical tasks, and students' appetite for plagiarism have become higher. These challenges can be sustainably managed via a procedure aimed at constructively converting students' appetite for plagiarism (SAP conversion) into a skill of critically approaching relevant materials that are available online. The solutions proposed by the specialized literature concerned with the problem of plagiarism can be grouped into five categories: better trained students, more involved teachers, the use of anti-plagiarism software, clear anti-plagiarism policies, and ethical education of the youths. The SAP conversion procedure is a solution targeting increased involvement on behalf of teachers. Its partial application in the case of the disciplines included in the undergraduate educational program of Sociology conducted by the Transylvania University of Brasov, where students' evaluation is based on essays, has considerably decreased the amount of student plagiarism.
\end{abstract}

Keywords: Internet; students; plagiarism; readymade solutions

\section{Introduction}

Learning contributes to knowledge perpetuation, and the latter supports community sustainable development by making previous experiences resulting from interaction with the world useful. At the same time, learning is a self-accomplishment tool and, as such, a goal of sustainable development. The future of communities and their members greatly depends on the way the learning processes foreshadow them in the present. There is always a stake in the changes performed in the educational field. Consequently, they must be assessed based on their outcomes at the generational level.

The Internet has recently acquired a widely acknowledged didactical utility [1-3], given its rather short history. The COVID-19 pandemic has highlighted the true dimensions and importance of the Internet in conducting educational processes. In many situations, access to resources that were available online was synonymous with access to training. The didactical role of the Internet is to become consolidated in the next period. Once acknowledged, the importance of the online component of the educational system is to gain increased significance. In such a context, examining the prospective threats accompanying that trend and searching for solutions to efficiently manage those threats is useful.

The Internet is not just a source of benefits in educational contexts. It favors, for example, the reliance on handy approaches incurring decreased intellectual involvement in accomplishing didactical tasks $[4,5]$. That is visible both when the solutions available online are incorporated as such in meeting didactical requirements, as well as in the case of students' plagiarism.

Some of the didactical requests formulated as part of the educational process, especially in the case of socio-humanities, concern the elaboration of essays and reports on 
a given topic. The curricula for general education and high school are elaborated at the national level. The syllabi of the academic programs are made by meeting the criteria and standards established at the national level too. Both syllabi and curricula are about to become homogenous at the European level. In such a context, the chances for pupils and students from various parts of the country/continent to be required to elaborate papers on similar topics are high. Additionally, in Romania, the examination topics for graduating from the general education level and high school (i.e., the Baccalaureate) are fixed, known by students, and used by the latter to prepare for the exams. Most likely such a situation is not a salient feature just for Romania. As a result, the creation of pools of solutions for the exam topics, readily available essays, and literary comments is the next step to follow.

The Internet efficiently hosts such pools of readymade solutions for examination topics which can be accessed by paying rather insignificant amounts of money or by uploading papers in exchange. The materials that are available on sites offering access to such pools provide correct and complete solutions for the didactical requirements made by the examination topics, and some of those are endorsed or elaborated by academic staff. They are useful as sources of knowledge. Nonetheless, their existence prevents students/pupils from finding their own solutions and discourages their creativity and critical thinking skills. When taking exams students are ranked based on their capacity to memorize and reproduce the solutions as such. As for undergraduate students, their appropriation of the materials that are available online is considered plagiarism even if the authors of those are not known. Either way, the increase in students' propensity for plagiarism is one of the effects associated with their wide unrestricted access to the Internet [4-11].

Concerning the readymade solutions, their accessibility discourages students from making any efforts towards accomplishing didactical tasks on their own and thus sabotages the development of the competencies targeted by the various disciplines. It also diminishes the chances to productively manage some future challenges raised by topics that are different from the ones served by the readymade solutions. The type of education and training favored by readymade solutions is past-oriented. It has no intention to capitalize on it in a fruitful manner. On the contrary, its ultimate goal is that of solely reproducing it in a repetitive and unproductive manner. We believe that is the reason partially accounting for the steady low scores obtained by Romanian students when taking the PISA exams (Programme for International Student Assessment) [12]. On the other hand, the explanation is complete when understanding that the theoretical approach to education and training outweighs the practical component in general education and the high school system. In this respect, that requires a separate, individual approach.

Acknowledging the source of the readymade solutions is in no way related to a sustainable educational process. The use of the Internet is closely associated with the tendency to plagiarize and that only adds to the unsustainable connotations underlying the choice of readymade solutions to meet didactical tasks. Acknowledging readymade solutions and the tendency to plagiarize are connected since they both show a gap between the goals established for the educational process and the evaluation of its results. Thus, they sabotage the sustainable conduct of the educational process. The question we thus ask concerns how their effects can be countered.

This article presents the answers we propose to the aforementioned question. The underpinning research endeavor leading to their formulation is centered on highlighting the main solutions proposed by specialized literature on the topic of students' plagiarism, and the means to constructively use students' appetite for plagiarism.

Presently, students' plagiarism is a phenomenon often encountered by the actors involved in the educational process [13-15]. Marques, Reis, and Gomes [16] view it as one of the most frequent departures from academic ethics. The academic interest in the phenomenon, as reflected by the studies and articles on this topic, is on the increase. A search for the term plagiarism in SpringerLink displays 101 papers on plagiarism published in 2000 and 10,994 available papers in January 2021 [17]. Thus, there is a large number of solutions to a problem which most authors view as closely connected to the wide access 
to Internet resources. We grouped the solutions by taxonomies, and we present them considering that they are useful for adopting various local and context-based strategies to solve/control the problem of student plagiarism.

Changing the perspective on the evaluation of students' educational performance depends on the wider educational context and educational policies. Such a change should consolidate students' self-confidence, creativity, and responsibility and hence would trigger sustainable consequences. A change in the perspective taken on education is a lengthy process. Until the change of perspective occurs, we deem that an intervention meant to correct and recalibrate didactical requests in order to make students' plagiarism void is efficient.

The recalibration we explicitly propose as a means to approach the problem of plagiarism implicitly diminishes the effects of acknowledging the sources of the readymade solutions. It forces students to use their minds in a creative and independent manner, thus making them become co-participants in the didactical process in a proactive manner. Its significant advantage lies in its capitalization on the skills already developed by students, as well as on the generous knowledge resources made available by the Internet. An additional advantage of recalibrating the didactical requests is its efficiency since it simultaneously counters students' tendency to plagiarize and the practice of using readymade solutions as already presented above. In this respect, we designed a procedure consisting of constructively converting students' appetite for plagiarism into a critical skill of critically approaching the relevant materials that are available online. We called it the SAP conversion. We will present the items characteristic of this procedure along with some of the results generated by its partial use as part of the didactical activities we ran with our students below.

\section{Materials and Methods}

We conducted comprehensive bibliographic research on the approaches of various studies and academic articles published for the past two decades on students' plagiarism. We thematically analyzed 60 papers on plagiarism published between 2000 and 2019 and indexed by the most important databases that can be accessed via the ANELIS Plus program as the most relevant. As a result of our analysis, we identified the following themes: a phenomenon on the increase, attempts towards taxonomies, the relative nature of approaches to students' plagiarism, causes and motivations of university students' plagiarism, solutions identified with regard to students' plagiarism. We will outline the contents related to the last topic in this article. The solutions proposed by the authors we consulted in this matter were grouped based on the taxonomy of the causes of plagiarism proposed by Sorea and Repanovici [18]. Thus, we grouped the identified solutions into five categories: better trained students, more involved teachers, the use of anti-plagiarism software, clear anti-plagiarism policies, and ethical education of the youths.

We highlighted what we deem to be the most efficient approach to students' plagiarism based on our own experiences with the issue, as well as in accordance with the solutions proposed by other academics as related to their own exposure to the phenomenon and based on them, we designed the SAP conversion procedure.

Over the last five years, we have monitored the behavior of students attending the undergraduate study program in Sociology organized by the Transylvania University of Brașov (Romania) for the disciplines we coordinate and that are evaluated (both during and at the end of the semester) by means of essays. The number of students evaluated per academic year is about 250 (out of a total of 1293 students). We have been monitoring the disciplines included in the curricula for the second and third years of study. We considered students' essays as social documents. During our evaluations, we analyzed their content in terms of the presence and the ratio of fragments of plagiarized text. We labeled the essays where at least one paragraph was reproduced without acknowledging its source as plagiarism and hence counted as such. We only took into account text-based plagiarism or patchwriting. The sources of plagiarism were identified by using Turnitin and/or Google. 
In order to identify the cases of patchwriting, the search for plagiarized sources was preceded by the partial reconstruction of the modified text. In most cases, the reconstruction involved replacing some terms with synonyms that best fit the context. We tracked the evolution in the number of plagiarized essays during successive examination periods organized for the second and third years of undergraduate studies, namely for the time period when we used items pertaining to the SAP conversion procedure in conducting didactical activities.

\section{Results}

The increased interest in plagiarism is reflected by the growing number of papers on the topic.

Thus, a simple search of the term plagiarism as the keyword in ScienceDirect [19] shows an increase in the number of papers published annually from 57 in 2000 to 476 in 2020. A similar search in SpringerLink [17] shows 101 papers published in 2000 and 1069 works published in 2020. The growth rates are graphically presented in Figure 1. The search in SpringerLink also reveals an increase in the total number of entries from 1479 in 2000 to 10,788 in 2020 (and 10,994 in January 2021, already). A graphic representation of this increase is presented in Figure 2.

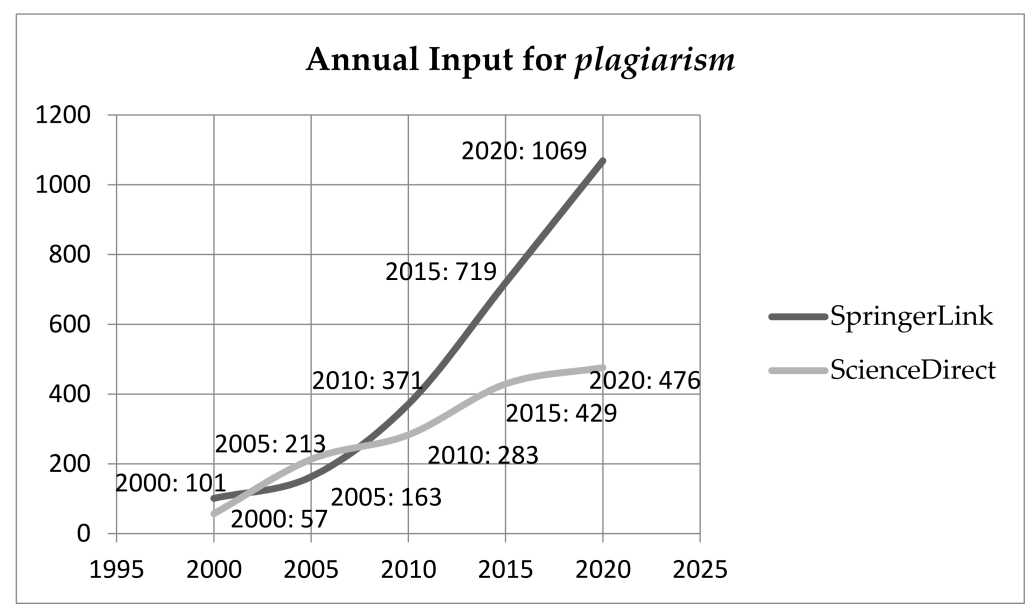

Figure 1. The increase in the number of plagiarism papers included in ScienceDirect and SpringerLink.

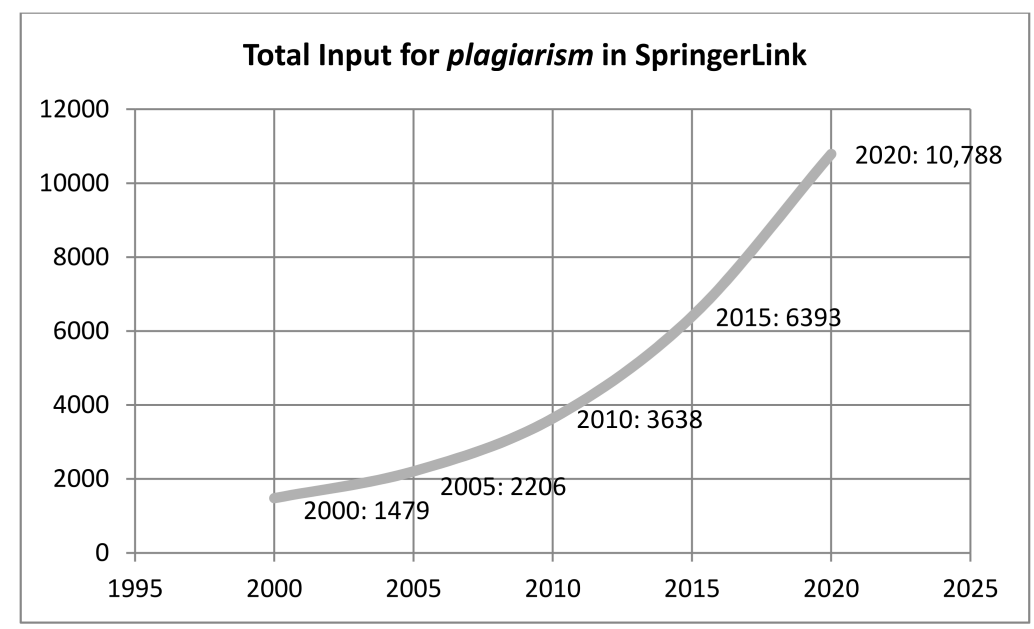

Figure 2. The increase in the total number of entries for plagiarism in SpringerLink between 2000 and 2020 . 


\subsection{Identified Solutions to the Problem of Students' Plagiarism}

Sorea and Repanovici [19] classify the causes of students' plagiarism in five categories, each of these with its own sub-categories: students, academics, Internet, institutional environment, and educational framework. We have grouped the solutions to students' plagiarism in the same categories.

\subsubsection{Better Trained Students}

As far as students are concerned, most of the solutions target the improvement of their education in relation to the rules of academic writing and plagiarism. In this respect, it is the students themselves who indicate this need [13]. Ramzan et al. [20] and Stabingis, Šarlauskiene and Čepaitienè [8] highlight that students want theoretical and practical knowledge about the use of sources, and Löfström and Kupila [1] show that students view full access to plagiarism reports as more useful than the presentation of results (that is similarity percentages). Students must be helped to learn how to write in an academic manner. Improving training [21-23] and increasing their awareness about plagiarism [12-14] would reduce the frequency of the phenomenon, as a number of authors indicate.

The results of several anti-plagiarism didactic initiatives were presented. Stetter [24] underlines the satisfaction of the participants to a web module on plagiarism and paraphrasing in relation to the increase of their knowledge in the field. Law, Ting, and Jerome [25] show that upon the completion of a course in academic writing students used fewer unethical quoting strategies. Additionally, Singh [26] highlights the usefulness of scientific writing workshops. Strittmatter and Bratton [27] emphasize the role of "Plagiarism and Ethics Awareness Training" or simply PEAT in educating students on how to quote sources, on how to adequately attribute ideas, and avoid theft of other people's ideas. Kier [28] pleads for the capacity of the tutorial for the game "Goblin Threat" to increase the ability of students to recognize plagiarized paragraphs (compared to the control group, the rate by which players recognized plagiarized paragraphs was $11 \%$ higher). Just using software like Turnitin could only favor superficial learning, whereas the tutorial facilitates understanding the information in the text, as Kier [19] shows. Yang, Stockwell, and McDonnell [29] describe the effects of a Writing in Your Own Voice intervention, which was conceived to help beneficiaries become aware of the types of plagiarism and avoid the writing problems as follows. For several weeks after its completion, the intervention reduced the cases of plagiarism along with the common writing problems by half, as well as the amount of serious plagiarism. Trautner and Borland [30] proposed a pedagogical exercise that employs sociological imagination in building and analyzing some scenarios about the reasons and consequences of unethical academic behavior. The exercise was developed for American students, but it can be easily adapted to various institutional contexts and it would help many others to simultaneously understand the personal and social implications triggered by the lack of integrity, in the authors' opinion.

Concerning students' lack of motivation as the main cause of plagiarism, Stabingis, Šarlauskienè, and Čepaitiene [8] underline the motivating role of switching the focus from the quantity of processed text to a qualitative approach on behalf of students, namely that is to originality and innovation.

\subsubsection{More Involved Teachers}

Most of the solutions to how teachers could reduce the frequency of students' plagiarism focus on the latter's more responsible involvement in managing the situation. That means overcoming the embarrassment that the identification and correction of plagiarism may generate.

It is necessary for teachers to change their attitudes so that students use the information available online adequately and formulate their own ideas, as Amiri and Razmjoo [5] show. Adam, Anderson, and Spronken-Smith [31] highlight that students consider feedback as a means to improve their writing without the pressure of sanctions. They view intercative personalized support as more useful than the general information published 
on the university website. Many authors believe that students must be supported to write their papers correctly from an academic point of view. Beginners should be assisted by their coordinators [32]. Students should be guided in planning their tasks and managing their resources, and they should be encouraged to write, despite fear of accidental plagiarism [1,31]. It is the teachers' job to explain to students the rules of academic writing, according to Gómez, Salazar, and Vargas [33], and they should also manage the pressures their students experience when elaborating their papers [20]. Critically assisting students by expanding their knowledge, unveiling the cultural dimension of writing conventions and their admission into the community of academic writing is more efficient than applying institutional policies targeting correction. The latter is intimidating and estranging for students because it affects their feeling of belonging to an academic community, considers Bell [34].

Acquiring academic writing skills is a process and that should not be ignored, according to some authors. Students should learn to write gradually with the aid of their teachers. Thus, if such an idea is taken into account, unintentional plagiarism could be approached in students' training processes and patchwriting could be corrected, show Adam, Anderson, and Spronken-Smith [31]. Ironically, students are asked to imitate their teachers-the educational process is a mimetic one-signals Bell [34]. Patchwriting should not be considered a transgression of academic norms, but an attempt at joining the academic environment and an opportunity to learn, according to the aforementioned author. If students are caught plagiarizing, they are warned, explained in what way they made a mistake, and asked to rewrite their paper. That gradually leads to a decrease in the number of plagiarized works, consider Vanbaelen and Harrison [13].

Teachers should (re)assume the whole responsibility of the educational process. The requests they formulate for their students must be properly formulated and clearly explained [26,27]. Merging theoretical concepts and practical applications, as it is specific for every individual subject matter, leads to a better understanding and application of the rules by which plagiarism can be avoided, show Powell and Singh [35]. Dias and Bastos [2] outline the benefits of developing cross-disciplinary competencies, innovative and attractive teaching solutions, and the advantages of orienting education toward creative individual work, rather than toward memorization and repetition. Direct, live interaction with an instructor increased the efficiency of the results obtained upon taking the web module on plagiarism and paraphrasing, according to the participants [24].

It is not just crude plagiarism that should be considered. Students may be more sensible about the recommended citation practices than it is generally stated, they have a positive attitude towards detection software, and the influence of Turnitin is higher among those who used it and it is proven to change the perception of plagiarism, show Childers and Bruton [36]. Students recognized verbatim plagiarism, the joining of fragments, and patchwriting, but it was more difficult for them to recognize the re-use of ideas as plagiarism. The discussion on the complex forms of the phenomenon should be more nuanced because, as the aforementioned authors show, if the discussions with students only focus on the verbatim forms of plagiarism, then their capacity to access academic writing is reduced. Concerning the relationship between teachers and students, Stabingis, Šarlauskienè, and Čepaitiene [8] underline the importance and the motivating role of mutual respect and trust. Teachers themselves should use new technologies, believe Heckler and Forde [7]. That would be one of the starting points for conveying their values to the next generation of students.

\subsubsection{Anti-Plagiarism Software}

As we mentioned in the Introduction, many authors attribute a central role to the Internet in the spread of student plagiarism, but the Internet also provides tools for detecting unethical academic practices.

The solutions concerning the role of the Internet in students' plagiarism focus on using detection programs that can be used precisely due to the Internet. Technology is 
a key aspect in the attempts of universities to reduce the frequency of plagiarism and Turnitin is the most adequate tool, according to Mphahlele and McKenna [3]. Löfström, Huotari, and Kupila [37] indicate that the introduction of text verification software changes, for the best, both teachers' and students' opinions on plagiarism and academic writing (there are also negative changes that are related to the erosion of trust). Singh [26] believes that the implementation of software and the obligation to check texts for plagiarism is a fundamental requirement for assuring the originality of the content of students' papers.

Some authors believe that the Internet can be retrieved as a didactic instrument because of the accessibility of the resources it hosts. Even students can appreciate the usefulness of detection software and such acknowledgment supports learning and understanding academic writing. Moreover, it motivates students to correctly use resources, incentivizes teachers to correctly teach the rules of academic writing, and dissuades dishonest students to obtain undeserved advantages, as Löfström and Kupila [1] highlight. Teachers' intent is first to check on their students, but detecting plagiarism has also a constructive dimension by developing students' writing skills and imposing the review of the guidelines on avoiding plagiarism, mention the same authors. The software is preponderantly misunderstood as being an instrument to detect plagiarism, while its educational potential should not be ignored, underline Mphahlele and McKenna [3]. Teachers should ask their students to produce summaries of the materials available online and self-evaluate with the aid of anti-plagiarism software, consider Granitz and Loewy [38]. Halupa, Breitenbach, and Anast [39] show that training focused on avoiding self-plagiarism is more efficient than general training on plagiarism and support its introduction into the academic curriculum. Dias and Bastos [2] suggest using anti-plagiarism software since secondary school.

\subsubsection{Clear Anti-Plagiarism Policies}

As far as the features of the institutional environment are concerned, the solutions identified focus on clarifying the anti-plagiarism rules and renouncing the tolerant attitude towards it.

According to Law, Ting, and Jerome [25] Gullifer and Tyson [40], Vassallo [41], Uzun and Kilis [23], it is necessary to formulate and unabatedly respect a policy on academic integrity. Codes of honor [11], a moral code [23], a textbook online accessible [22] on university websites should be elaborated. $\mathrm{Li}$ [42] proposes the editing of an online available handbook elaborated by COPE (The Committee on Publication Ethics). There should be strict enforcement of sanctions for plagiarism [11,22]. Universities should support reporting on plagiarism. Clemency towards it is not useful and should be replaced by innovative and authentic research, indicate Amiri and Razmjoo [5].

All involved actors should be familiar with the rules of academic writing, consider the authors of some studies. It is necessary to clearly explain expectations, rules of academic writing, and what the adequate resources are to students, point out Gómez, Salazar, and Vargas [33]. Specific policies concerning plagiarism must be promoted $[7,14,43]$. They need to be student-centered, easily accessible, efficiently approached from an educational perspective and they should indicate clear roles and responsibilities [44]. Ramzan et al. [20] propose the organization of seminars, workshops, and symposia on plagiarism. Law, Ting, and Jerome [25] highlight the dwindling of the number of incorrect citations as a result of the courses on the correct use of bibliography. Gunnarsson, Kulesza, Pettersson [45] show the positive feedback obtained during a course on research methodology run in collaboration with teachers and librarians at the master's program level and composed of two parts: one was concerned with the correct use of sources while the other focused on the legal and ethical aspects of plagiarism. Mansoor and Ameen [15] in their turn mention the role of librarians in fighting plagiarism when attributing these the informal role of irregular counselors on anti-plagiarism. Additionally, Gibson and Chester-Fangman [46], refer to the formal framework provided by libraries as a means of training students on plagiarism and thus preventing it. As always, prevention is more efficient than sanctioning. Proactive learning in relation to plagiarism and its avoidance would be more useful than 
its detection by specialized software, believe Jereb et al. [22]. Knowlton and Collins [47] support a change in the reactive and punishing attitude of academics to more proactive and preventive behavior. In this respect, they show that encouraging students to actively use anti-plagiarism software before submitting their papers would teach them to prevent the phenomenon in a more useful manner than punishing them after submitting the papers. University policies on the issue can change if the experience shared by faculty members proves that the approach to plagiarism can be more useful if it is treated as a stage in the learning process rather than as an opportunity for immediate punishment, according to Stowe [48]. Even in the context of sanction-oriented policies, a continuous dialogue among teachers and between them and university leadership on plagiarism and its implications for the academic community is important. Such a dialogue reveals the attitudes of universities and their experience in relation to students' plagiarism, indicates the previously mentioned author.

Institutions must acknowledge the potential of the tensions arising from establishing clear rules and explicit procedures concerning the management of plagiarism and teachers autonomy, show Peytcheva-Forsyth, Mellar, and Aleksieva [49]. They believe that the increased involvement in European and e-learning projects leads universities toward the improvement of their procedures in the field of correct academic writing. Pandoi, Gaur, and Gupta [50], in full awareness of the originality of their solution, suggest that universities should shame students with value-focused messages, which by their manipulative potential could keep the problem of students' plagiarism under control.

According to Stabingis, Šarlauskienè, and Čepaitienè [8], in the universities of Lithuania, there are mostly four types of prevention measures: adopting codes of ethics, training and consulting students, monitoring their progress, and internally evaluating the quality of the didactic approaches.

\subsubsection{Ethical Education of the Youths}

Concerning the educational framework, solutions target the alignment of the approaches to plagiarism to the cultural context in which it occurs and also the consolidation of the ethical dimension of the educational process.

Pennycook [51] shows that the relations between texts and learning are more complex than those revealed by a simple accusation of plagiarism. Many of the approaches to alleged plagiarism are tactless from a pedagogical perspective and intellectually arrogant. The conclusions that students plagiarize and the requirement for them to learn how to correctly write academically become adequate when they are related to the cultural and historical features that characterize each of these students. Their relation to texts and memory can be very different, according to the aforementioned author.

Chinese culture is frequently associated with copying and that explains the interest of the Chinese authors to manage plagiarism. According to Kelm and Sharon [52], this is a constructive approach since it focuses on the production of ethically correct texts. Highlighting the dialectic relation between copying and imitating guides students in finding honest solutions for their didactical tasks. Students can be explicitly taught how to avoid the corrupt borrowing of someone else's writing, shows Li [32].

The rules of academic writing can be correct and appropriate, but students must also learn that plagiarism is an ethical problem. Students must know why plagiarism corrodes and destroys the moral tissue of culture and society, underline Strittmatter and Bratton [27]. Jereb et al. [22] indicate that it is the key task of both the educational system and society at large to educate the youths on morality and ethics when they are teenagers. Since students learn from their teachers, academic integrity should be crucial in their development, show Uzun and Kilis [23].

\subsubsection{Building upon Already Manifest Trends in Using the Internet}

The solutions presented above are, in most cases, focused on preventing, deterring, and sanctioning plagiarism. 
We believe that Rosenberg [53] is right to view the problem of students' plagiarism from Kant's categorical imperative perspective. At the risk of offending honest students and considering them all innocent until proven otherwise, teachers need to check their work for plagiarism. If not, they run the risk of being mere instruments, means by which students achieve their goals, and that only leads to undermining the trust that should exist in the teacher-student relationship.

East [54], Löfström and Kupila [1] also believe that the teachers who have the correct attitude towards students' plagiarism act to the students' and academic community's benefit.

Nonetheless, we believe that to be consistent in approaching others (i.e., university students) as goals, there should be a shift from focusing on detecting and signaling the presence of plagiarism toward creating a climate conducive to perceiving it as inappropriate. As Townley and Parsell [55] considered, the efforts concerning this phenomenon should be redirected from providing technological solutions to the problem of unethical academic behavior to the support of an intellectual community upholding academic and ethical principle, and to indirectly teach students how to plagiarize without being caught does not contribute to this. Focusing on detecting, denouncing, and sanctioning plagiarism is an adequate solution for treating the symptoms. An efficient approach targets motivation.

Additionally, sanctions do not seem to be able to prevent people from being willing to plagiarize [50], and the technical training related to the correct use of research resources does not seem to be sufficient in preventing plagiarism [56].

Efficiency is about gaining maximum results for minimum effort. Thus, in our case, an efficient approach would focus on demotivating students from plagiarizing. If that is to be done by building upon trends that are already manifest, all the better.

Students have discovered and have been using the Internet for a long time. Projectbased learning encourages the use of the resources that are available online, but it implicitly may encourage plagiarism [19,57].

Project-based learning resumes William Kilpatrick's child-centered learning $[58,59]$ and is a form of collaborative learning. "Briefly, based on the constructivist background, the project approach represents a student-centered pedagogy, a comprehensive instructional endeavor which consists of individual, small, or larger group in-depth extended investigation of a topic or problem, worthy of the student's interests, energy, and time" [60] (p.57). The students who benefit from project-based learning gain more self-confidence, get better results in school, pay more attention [59], are more independent and open, remember better what they learn, and get better results when evaluated [60]. However, in the case of many future university students, these benefits are accompanied by their habit of using the Internet with no ethical constraints. In the pre-university educational system, school projects are assessed by their content, not by the accuracy in employing references. That is a representation of how to use the Internet that students gain before enrolling in academic programs and it is one of the causes leading to a large number of plagiarized work among university students. It is the side effect of a generous educational approach.

The Internet is an efficient didactical instrument. The habit of using Internet-based resources should not be discouraged. It must be efficiently and ethically capitalized on. Most of the solutions focus on persuading students that plagiarism is an undesirable (dishonest, useless, and dangerous because of its consequences) practice. However, this type of solution implicitly restrains students' interest in using the Internet and that does not benefit anybody. As Löfström and Kupila [1] show, the fear of plagiarism diverts attention from the very cumulative nature of knowledge and from the rules of academic writing. Moreover, the interest in detecting and punishing plagiarized work is against current trends in promoting desirable behavior.

We believe that the solutions focused on sanctioning plagiarism become useful only as a secondary type of instrument that supports truly efficient solutions like retrieving the Internet from a didactical perspective and as an instrument contributing to knowledge development.

We agree with Townley and Parsell [55] who underline that in the fight between students and teachers over the dishonest use of the Internet the latter are at a disadvantage. 
This is the classical situation of the upper hand obtained by the one who commits a crime over the one who is supposed to conduct investigation work and to sanction. There are very many chances for students to find increasingly sophisticated means to counter the attempts meant to detect their unethical behavior. The foreseeable failure of teachers in this context is also an injustice made to honest students.

If university students feel tempted to search and appropriate the solutions that have been proposed by others and that meet their school-related requirements, then we believe it is more efficient for them to be asked to explain and comment on what they find. Plagiarism will no longer be encouraged if university students are asked to identify the relevant information sources for a given topic and to present their content along with their own opinions.

Within this context, the solution we propose is meant to demotivate students from plagiarizing. If the didactical requirement were to change from asking students to simply present a topic to critically present it, namely asking them to refer to alternative approaches to the topic under discussion from specialized literature, then students would need to comment on the relevant materials which are available online. They would no longer be able to plagiarize those materials. The effort made to find materials that would approach the sources initially discovered in a critical manner would be too great. Consequently, that might encourage students to formulate their own critical remarks. Thus, plagiarism would be rendered useless.

\subsubsection{How to Efficiently Retrieve the Didactical Use of the Internet: SAP Conversion}

Plagiarism does not automatically lose its power when it is associated with a request of a teacher to a student. The request must be supported by supplementary measures. Rets and Ilya [21] present a series of such actions: asking students to complete creative tasks that require the use of their critical thinking skills; requiring students to elaborate a portfolio that should not only contain the final version of the writing task but also all the sketches, as well as some copies of the resources used in the writing process; continuous evaluation of the progress of the critical approach based on feedback. We deem such approaches appropriate for deterring students from plagiarizing. In the paragraphs to follow we will present some of the measures that we propose in order to divert students' intention to plagiarize and constructively employ their skills in using the Internet. The proposed measures are anchored in Granitz and Loewy's [38] suggestion that teachers require their students to summarize some of the materials available online. We grouped these into a procedure on the constructive conversion of students'appetite for plagiarism into a skill of critically approaching the relevant materials that are available online (SAP conversion):

- (a) Training students on how to differentiate between academically trustworthy texts from unreliable ones;

- (b) Directly coordinating the choice of bibliographical materials by students requires supplementary effort on behalf of teachers but ensures high efficiency since it prevents students from selecting the same materials and hence from "borrowing" summaries and critical comments, or the illegitimate sharing of attributions in fulfilling the task; moreover, if teachers are at least partially involved in establishing what materials students are to process, the quality of discussions and of documentation for undergraduate theses increases as a result of the collection of texts that is thus established.

- (c) Asking students, whenever possible, to include the bibliography in (the electronic form of) the evaluation portfolio in order to avoid or at least reduce the number of copy-paste fragments used in the presentation of the work submitted by students;

- (d) Asking students to introduce a minimum number of summaries (i.e., students') of recent articles on a given topic into the portfolio;

- (e) Asking students to include in their evaluation portfolio an obligatory number of articles from specialized journals acknowledged by the Ministry and/or by publications recognized by famous databases in order to limit the choice of easily retrievable materials over relevant ones. To employ such a requirement as a mandatory one is 
useful in many ways and does not limit the sources of materials that students can deem relevant; on the contrary, such a requirement does not only render plagiarism useless but also helps students sense the trend in relation to the issues they investigate. Additionally, it indirectly teaches them to comply with academic writing standards that they implicitly encounter when reading the texts that they need to include in their portfolio;

- (f) Asking students to attach an antiplagiarism evaluation report for the essay into the portfolio;

- (g) Detailed reporting of plagiarism (i.e., plagiarized source, the ratio of plagiarized text in the essay) and description of its impact on evaluation results;

- (h) Granting the opportunity to redo plagiarized essays.

- If all of the above requirements and clarifications are clearly presented as rules of a game that has as a stake the acceptance of the evaluation portfolio, they are to be acquired by students since, after all, one of university students' salient features is their capacity to learn.

The sum of requests detailed by the procedure makes the use of readymade solutions almost impossible. The students are thus forced to critically think of their essays and elaborate on them on their own. The readymade solutions that are available online become bibliography - that is, what is natural and useful, and not materials that can be used in the copy-paste manner.

We present some of the results we obtained as a result of applying some of the items characteristic of the procedure we propose in our didactical activities in order to support the claim we make concerning its efficiency. We have been using items from the already presented procedure with our students for some years. The items we refer to are items a, c, $\mathrm{e}, \mathrm{g}$, $\mathrm{h}$. We believe their use is efficient.

The essays we analyzed were elaborated as part of the academic requirements starting from the first semester of the second year of study and until the end of the third year of the Sociology study program. Based on archived evaluation results we established the evolution of the weight of plagiarism cases during the study years.

The rate of plagiarism attempts is around $40 \%$ (203/502) in the case of the first essays $(502 / 1293)$ presented for evaluation in a discipline taught in the third semester of study, and it gradually decreases to $10 \%$ in the case of the assessments of a similar type to students in the final years. In order to exemplify we present in Table 1 the evolution of plagiarism in the case of the disciplines coordinated by the same academic during three consecutive semesters (semester III, IV, and V, respectively).

Table 1. Weight of plagiarism for the past five years.

\begin{tabular}{llllllllll}
\hline Class & \multicolumn{2}{l}{ Semester III } & \multicolumn{3}{l}{ Semester IV } & \multicolumn{3}{c}{ Semester V } \\
\hline & $\begin{array}{l}\text { Essays } \\
\text { Evaluated }\end{array}$ & $\begin{array}{l}\text { Cases of } \\
\text { plagiarism }\end{array}$ & $\begin{array}{l}\text { Weight of } \\
\text { plagiarism }\end{array}$ & & & & & & \\
& (a) & $(\mathrm{b})$ & $(\mathrm{c}=\mathrm{b} / \mathrm{a})$ & (a) & (b) & (c) & (a) & (b) & (c) \\
\hline $2018-2021$ & 39 & 14 & 0.35 & 38 & 12 & 0.32 & Missing data \\
\hline $2017-2020$ & 42 & 17 & 0.40 & 42 & 12 & 0.29 & 40 & 5 & 0.13 \\
\hline $2016-2019$ & 52 & 28 & 0.54 & 52 & 19 & 0.37 & 48 & 7 & 0.15 \\
\hline $2015-2018$ & 39 & 18 & 0.46 & 39 & 8 & 0.21 & 39 & 4 & 0.10 \\
\hline $2014-2017$ & 36 & 20 & 0.55 & 36 & 20 & 0.55 & 31 & 2 & 0.06 \\
\hline
\end{tabular}

Figure 3 shows graphically the decrease in the weight of plagiarism in the disciplines in the table in the case of 2017, 2018, 2019, and 2020 classes. In the case of the 2018/2021 class, the discipline monitored in the third year of study is to be studied during semester VI. 


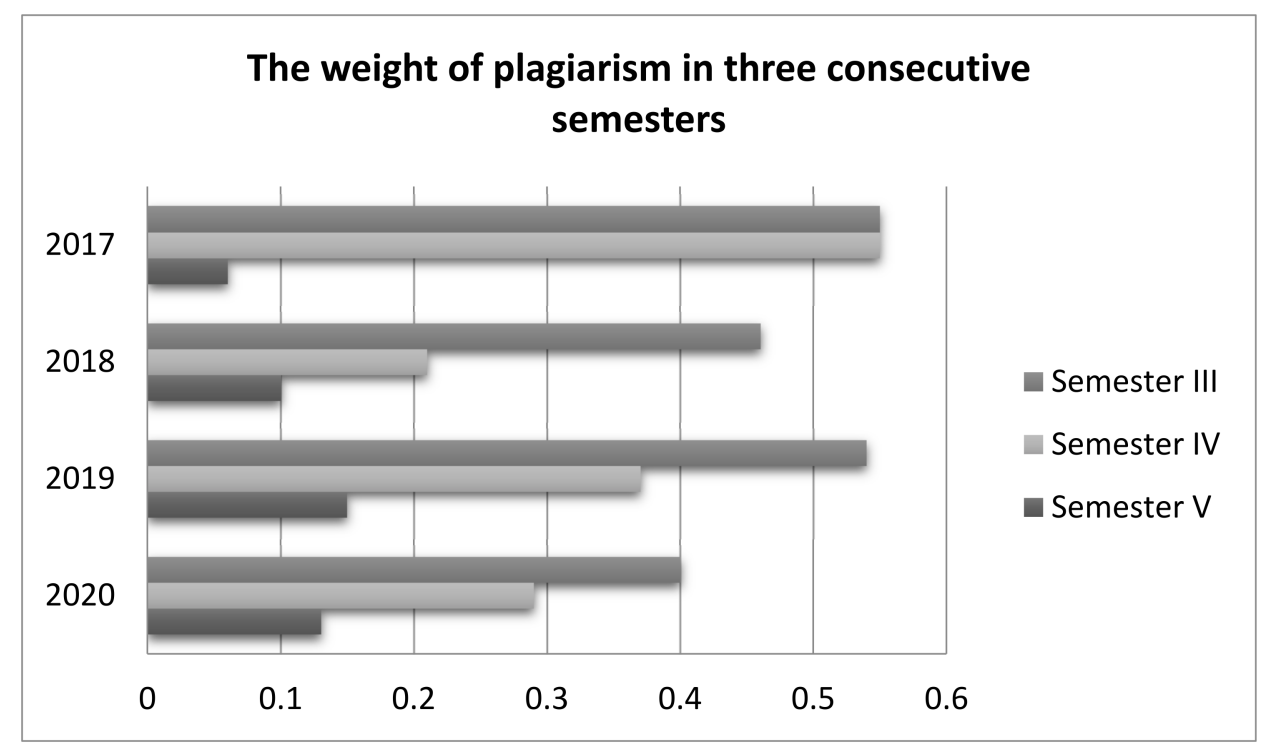

Figure 3. Decrease in the weight of plagiarism during three consecutive semesters.

In most cases (around 90\%), the plagiarized sources are among the first options listed while doing a simple search on Google. In most essays, different students sharing the same topic and even different generations use the same sources. The style of plagiarized texts is an efficient indicator of plagiarism. The sentence structure and the vocabulary are not characteristic of undergraduate students' writing style. They show writing skills that usually students have not acquired yet and, by the formulations used, that the authors of the essays belong to previous generations. These rank among the first indicators leading to the assumption of plagiarism before the actual checking of the text in this respect. In the other cases (around 10\%) the plagiarized sources are students' essays downloaded from specialized sites: Scribd, RegieLive, Referat.ro, EreferateRo, Tocilar.ro, etc. In the case of essays written at the beginning of their study, there is a marked tendency to plagiarize large parts of a text and sometimes a whole essay would be made of such a chunk of text. By the end of studies, the number of plagiarized parts in an essay decreases and there are more frequent cases in which the excerpts from various sources are presented successively. In most cases (around 96\%) it is about verbatim plagiarism. In the other essays, the students opted for patchwriting. We suspect that they used software to replace synonyms because the chosen terms are often inappropriate in the context. As previously shown, their replacement with terms frequently used in the linguistic contexts characteristic of a given text allows for the identification of plagiarized text.

The decrease in the rate of plagiarism attempts is accompanied by the occurrence of camouflaged intentions to plagiarize (de-plagiarism, as Wrigley calls it, [61]). We identified several such practices aimed at preventing/making the detection of plagiarism more difficult: changing the fonts of one or of several characters in the text (usually the fonts of vowels a, e, or i), the introduction of blind characters, or joining some prepositions or conjunctions with the words next to them in order to prevent the electronic identification of the source of the text, etc. We consider that such practices require a separate approach that should focus on the ethics of academic writing.

The application of the current procedure, which we deem is an increased version of the procedures we have employed for the past few years, will increasingly reduce the rate of plagiarism among our students. The procedure we propose requires teachers' extra effort and responsibly acknowledging students' plagiarism as a problem. Therefore, even if it requires students' effort, as well as using the Internet as an instrument, we believe that its place in the classification of identified solutions for plagiarism is at the level of more involved teachers. 


\section{Discussion and Conclusions}

Mphahlele and McKenna [3] show that technology plays a major role in the attempts of universities to reduce the incidence of plagiarism and, as we have already mentioned, they consider Turnitin as the best detection tool. However, Turnitin is not perfect. It works well in the case of textual plagiarism, but not in the case of intelligent plagiarism such as paraphrasing, translations, expressing ideas, or presenting research results without acknowledging their source [53,62]. To detect cross-language plagiarism, there are various software solutions, such as the fuzzy semantic-based model [63], the segmentation by keywords [64], or the continuous word alignment-based similarity analysis [65]. Nonetheless, in the case of universities, Turnitin is, for now, the most accessible instrument considering the large amount of text to be verified. In the case of our students, the inefficiency of Turnitin in identifying texts plagiarized via translation is partially compensated by the fact that they use Google Translate without correcting the resulting text or they just correct it in a shallow manner. That is a situation that is more frequent in the case of final graduation papers rather than in the case of essays written for discipline evaluation purposes, as a result of the greater pressure to use important references in the first case. The linguistic formulations provided by Google Translate are more often than not inadequate or they lack the finesse of a good speaker of the Romanian language-a language of Latin origin whose sentence structure is heavily influenced by Slavic [66]. This even turns the translation provided by Google into an indicator of plagiarism.

In addition, the effectiveness of Turnitin, which acts by considering each student as a possible plagiarist [55], depends on the size of its available database. Thus, it does not detect the plagiarism of texts which are not part of its database, such as texts from old treaties. On the other hand, every text (even drafts of future papers) that is included in the Turnitin database is treated as available for plagiarism. Therefore, the percentage of plagiarism indicated by the software must be interpreted in relation to the detailed report on plagiarized sources. Consequently, the use of Turnitin as an instrument to counter plagiarism requires responsibility and discernment of the academic staff.

The Internet is a wide source of knowledge. It is a source for increasing the efficiency of teaching [38] and an opportunity for students [20]. Zarfsaz and Ahmadi [9] underline that the main source of information on plagiarism is the Internet in the case of students. On the other hand, the skills required to use the Internet also represent tools for the detection of unethical academic practices [4].

These are arguments that further corroborate the solution we propose. Capitalizing on existing skills is more efficient than encouraging the reluctance to use the Internet. Additionally, Singh [26] points out that there are no significant differences in the frequency of plagiarism between the students who use the Internet and those who use printed sources. Accordingly, the practice of plagiarizing is not necessarily connected to the ease of access to the resources which are available online. It could indicate a general human tendency to minimize (any kind of) effort for gaining the same benefits.

We reckon that the lesson of the pandemic will consolidate the Internet as an acknowledged tool and framework for the development of the educational process. Within this context, the stake of efficiently using the Internet is increasingly high. The solution we suggest is efficient for several reasons. First, it forces students to responsibly and attentively interpret relevant information as provided by the sources available online. It teaches students to express their opinions based on arguments instead of reproducing other people's views, with which they sometimes do not necessarily agree. It instructs them how to constructively use their instruments and not simply disseminate other people's ideas.

We believe the solution we propose is a sustainable approach to students' plagiarism because it converts already existing skills that are sanctionable into skills that contribute to a healthy academic environment. Additionally, it supplies useful long-term instruments. Furthermore, it suggests the efficient use of a resource that is generally acknowledged as valuable. 
SAP conversion does not undermine the effectiveness of the other solutions suggested to solve the problem of students' plagiarism. On the contrary, we believe that all these solutions build one upon the other. We believe that their arrangement by categories in the previous paragraphs puts them in the limelight for academic staff and thus supports them in making optimal decisions in relation to their challenge of managing plagiarism. Local educational contexts calibrate the usefulness of available solutions. Identifying the most efficient solutions is academic staff's responsibility. They can mold students' behavior and the importance attributed to online resources used in the educational process. Moreover, they can impose institutional policies through their representatives. In the long term, by fulfilling their roles of shaping behavior and forming opinions, they can change the entire educational context. We believe that the academic staff is the main actor involved in the approaches meant to tackle the problem of students' plagiarism.

Author Contributions: Conceptualization, D.S., and G.R.; methodology, D.S.; validation, D.S., G.R., and A.-M.B.; investigation, D.S., G.R., A.-M.B.; writing-original draft preparation, D.S.; writingreview and editing, D.S., G.R., A.-M.B.; supervision, D.S. All authors have read and agreed to the published version of the manuscript.

Funding: This research received no external funding.

Institutional Review Board Statement: Not applicable.

Informed Consent Statement: Not applicable.

Data Availability Statement: https:/ / link.springer.com/search?query=plagiarism; https:/ /www. sciencedirect.com/search?qs=plagiarism (accessed on 10 February 2021).

Conflicts of Interest: The authors declare no conflict of interest.

\section{References}

1. Löfström, E.; Kupila, P. The Instructional challenges of student plagiarism. J. Acad. Ethics 2013, 11, 231-242. [CrossRef]

2. Dias, P.C.; Bastos, A.S. Plagiarism phenomenon in European countries: Results from GENIUS project. Procedia Soc. Behav. Sci. 2014, 116, 2526-2531. [CrossRef]

3. Mphahlele, A.; McKenna, S. The use of Turnitin in the higher education sector: Decoding the myth. Assess. Eval. High. Educ. 2019, 44, 1079-1089. [CrossRef]

4. Comas-Forgas, R.; Sureda-Negre, J. Academic plagiarism: Explanatory factors from students' perspective. J. Acad. Ethics 2010, 8, 217-232. [CrossRef]

5. Amiri, F.; Razmjoo, S.A. On Iranian EFL Undergraduate Students' Perceptions of Plagiarism. J. Acad. Ethics 2016, 14, 115-131. [CrossRef]

6. Dias, P.C.; Bastos, A.S. Plagiarism in Portugal-Secondary education teachers' perceptions. Procedia Soc. Behav. Sci. 2014, 116, 2598-2602. [CrossRef]

7. Heckler, N.C.; Forde, D.R. The Role of Cultural Values in Plagiarism in Higher Education. J. Acad. Ethics 2014, 13, 61-75. [CrossRef]

8. Stabingis, L.; Šarlauskienè, L.; Čepaitienè, N. Measures for plagiarism prevention in students' written works: Case study of ASU experience. Procedia Soc. Behav. Sci. 2014, 110, 689-699. [CrossRef]

9. Zarfsaz, E.; Ahmadi, R. Investigating Some Main Causes and Reasons of Writing Plagiarism in an EFL Context. Int. J. Appl. Linguist. Engl. Lit. 2017, 6, 214-223. [CrossRef]

10. Chen, Y.; Chou, C. Are We on the Same Page? College Students' and Faculty's Perception of Student Plagiarism in Taiwan. Ethics Behav. 2017, 27, 53-73. [CrossRef]

11. Maloshonok, N.; Shmeleva, E. Factors Influencing Academic Dishonesty among Undergraduate Students at Russian Universities. J. Acad. Ethics 2019, 17, 313-329. [CrossRef]

12. Rezultatele Elevilor din România la Evaluarea Internațională PISA. 2018. Available online: https://www.edu.ro/rezultateleelevilor-din-rom\%C3\%A2nia-la-evaluarea-interna\%C8\%9Bional\%C4\%83-pisa-2018 (accessed on 10 February 2021).

13. Vanbaelen, R.; Harrison, J. Plagiarism awareness. In Proceedings of the IEEE International Conference on Professional Communication (IPCC), Vancouver, BC, Canada, 15-17 July 2013; pp. 335-342. [CrossRef]

14. Halupa, C.M.; Bolliger, D.U. Faculty Perceptions of Student Self Plagiarism: An Exploratory Multi-University Study. J. Acad. Ethics 2013, 11, 297-310. [CrossRef]

15. Mansoor, F.; Ameen, K. Promoting Academic Integrity in South Asian Research Culture: The Case of Pakistani Academic Institutions. A Res. J. South Asian Stud. 2016, 32, 77-90. 
16. Marques, T.; Reis, N.; Gomes, J. A Bibliometric Study on Academic Dishonesty Research. J. Acad. Ethics 2019, 17, 169-191. [CrossRef]

17. Available online: https://link.springer.com/search?query=plagiarism (accessed on 10 February 2021).

18. Sorea, D.; Repanovici, A. Project-based learning and its contribution to avoid plagiarism of university students. Investig. Bibl. 2020, 34, 155-178. [CrossRef]

19. Available online: https://www.sciencedirect.com/search?qs=plagiarism (accessed on 10 February 2021).

20. Ramzan, M.; Munir, M.A.; Siddique, N.; Asif, M. Awareness about plagiarism amongst university students in Pakistan. High. Educ. 2012, 64, 73-84. [CrossRef]

21. Rets, I.; Ilya, A. Eliciting ELT Students' Understanding of Plagiarism in Academic Writing. Eurasian J. Appl. Linguist. 2018, 4, 193-211. [CrossRef]

22. Jereb, E.; Urh, M.; Jerebic, J.; Šprajc, P. Gender differences and the awareness of plagiarism in higher education. Soc. Psychol. Educ. 2018, 21, 409-426. [CrossRef]

23. Uzun, A.M.; Kilis, S. Investigating antecedents of plagiarism using extended theory of planned behavior. Comput. Educ. 2020, 144, 103700. [CrossRef]

24. Stetter, M.E. Teaching students about plagiarism using a web-based module. J. Furth. High. Educ. 2013, 37, 675-693. [CrossRef]

25. Law, L.; Ting, S.H.; Jerome, C. Cognitive dissonance in dealing with plagiarism in academic writing. Procedia Soc. Behav. Sci. 2013, 97, 278-284. [CrossRef]

26. Singh, N. Level of awareness among veterinary students of GADVASU towards plagiarism: A case study. Electron. Libr. 2017, 35, 899-915. [CrossRef]

27. Strittmatter, C.; Bratton, V. Teaching Plagiarism Prevention to College Students: An Ethics Based Approach; Rowman and Littlefield Publishing: Lanham, MD, USA, 2016.

28. Kier, C.A. Plagiarism Intervention Using a Game-Based Tutorial in an Online Distance Education Course. J. Acad. Ethics 2019, 17, 429-439. [CrossRef]

29. Yang, A.; Stockwell, S.; McDonnell, L. Writing in your own voice: An intervention that reduces plagiarism and common writing problems in students' scientific writing. Biochem. Mol. Biol. Educ. 2019, 47, 589-598. [CrossRef] [PubMed]

30. Trautner, M.N.; Borland, E. Using the Sociological Imagination to Teach about Academic Integrity. Teach. Sociol. 2013, 41, 377-388. [CrossRef]

31. Adam, L.; Anderson, V.; Spronken-Smith, R. "It's not fair": Policy discourses and students' understandings of plagiarism in a New Zealand university. High. Educ. 2017, 74, 17-32. [CrossRef]

32. Li, Y. Text-based plagiarism in scientific writing: What Chinese supervisors think about copying and how to reduce it in students writing. Sci. Eng. Ethics 2013, 19, 569-583. [CrossRef]

33. Gómez, J.; Salazar, I.; Vargas, P. Dishonest Behavior and Plagiarism by University Students: An Application to Management Studies. Procedia Soc. Behav. Sci. 2013, 83, 766-770. [CrossRef]

34. Bell, S. Addressing student plagiarism from the library learning commons. Inf. Learn. Sci. 2018, 119, 203-214. [CrossRef]

35. Powell, L.; Singh, N. An integrated academic literacy approach to improving students' understanding of plagiarism in an accounting course. Account. Educ. 2016, 25, 14-34. [CrossRef]

36. Childers, D.; Bruton, S. "Should It Be Considered Plagiarism?" Student Perceptions of Complex Citation Issues. J. Acad. Ethics 2016, 14, 1-17. [CrossRef]

37. Löfström, E.; Huotari, E.; Kupila, P. Conceptions of plagiarism and problems in academic writing in a changing landscape of external regulation. J. Acad. Ethics 2017, 15, 277-292. [CrossRef]

38. Granitz, N.; Loewy, D. Applying ethical theories: Interpreting and responding to student plagiarism. J. Bus. Ethics 2007, 72, 293-306. [CrossRef]

39. Halupa, C.M.; Breitenbach, E.; Anast, A. A Self-Plagiarism Intervention for Doctoral Students: A Qualitative Pilot Study. J. Acad. Ethics 2016, 14, 175-189. [CrossRef]

40. Gullifer, J.; Tyson, G. Who has read the policy on plagiarism? Unpacking students' understanding of plagiarism. Stud. High. Educ. 2014, 39, 1202-1218. [CrossRef]

41. Vassallo, J. WASP (Write a Scientific Paper): Plagiarism and the ethics of dealing with colleagues. Early Hum. Dev. 2018, 124, 65-67. [CrossRef]

42. Li, Y. Text-based plagiarism in scientific publishing: Issues, developments and education. Sci. Eng. Ethics 2013, 19, 1241-1254 [CrossRef]

43. Hofmann, B.; Myhr, A.I.; Holm, S. Scientific dishonesty-A nationwide survey of doctoral students in Norway. BMC Med. Ethics 2013, 14, 3. [CrossRef]

44. Stoesz, B.M.; Eaton, S.E.; Miron, J.; Thacker, E.J. Academic integrity and contract cheating policy analysis of colleges in Ontario, Canada. Int. J. Educ. Integr. 2019, 15, 1-18. [CrossRef]

45. Gunnarsson, J.; Kulesza, W.J.; Pettersson, A. Teaching International Students How to Avoid Plagiarism. Librarians and Faculty Collaboration. J. Acad. Librariansh. 2014, 40, 413-417. [CrossRef]

46. Gibson, N.S.; Chester-Fangman, C. The librarian's role in combating plagiarism. Ref. Serv. Rev. 2011, 39, 132-150. [CrossRef]

47. Knowlton, M.; Collins, S.B. Foreign-Educated Graduate Nursing Students and Plagiarism. J. Nurs. Educ. 2017, 56, 211-214. [CrossRef] [PubMed] 
48. Stowe, S. Will They Or Not? Online Faculty Intentions To Report Student Plagiarism. Acad. Educ. Leadersh. J. 2017, 21, 1-18.

49. Peytcheva-Forsyth, R.; Mellar, H.; Aleksieva, L. Using a Student Authentication and Authorship Checking System as a Catalyst for Developing an Academic Integrity Culture: A Bulgarian Case Study. J. Acad. Ethics 2019, 17, 245-269. [CrossRef]

50. Pandoi, D.; Gaur, S.S.; Gupta, A.K. Role of virtues in the relationship between shame and tendency to plagiarise: Study in the context of higher education. Int. J. Educ. Manag. 2019, 33, 66-85. [CrossRef]

51. Pennycook, A. Borrowing Others' Words: Text, Ownership, Memory, and Plagiarism. TESOL Q. 1996, 30, 201-230. [CrossRef]

52. Kelm, K.M.; Sharon, T. When It Comes to Plagiarism-Nationality Matters! Results of an Empirical Study Extended Abstract. In In Proceedings of the 19th Annual Sloan Consortium International Conference on Online Learning, Lake Buena Vista, FL, USA, 20-23 November 2013.

53. Rosenberg, M. Principled Autonomy and Plagiarism. J. Acad. Ethics 2011, 9, 61-69. [CrossRef]

54. East, J. Judging plagiarism: A problem of morality and convention. High. Educ. 2010, 59, 69-83. [CrossRef]

55. Townley, C.; Parsell, M. Technology and academic virtue: Student plagiarism through the looking glass. Ethics Inf. Technol. 2004, 6, 271-277. [CrossRef]

56. Krokoscz, M.; Ferreira, S. Perceptions of Graduate Students at the University of São Paulo about Plagiarism Practices in Academic Works. An. Acad. Bras. Cienc. 2019, 91, e20180196. [CrossRef]

57. Sorea, D.; Borcoman, M.; Rățulea, G. Factors that influence students' attitude towards copying and plagiarism. In Proceedings of the International Conference on Intellectual Property and Information Management (IPM '11), Brasov, Romania, 7-9 April 2011; Murzea, C.L.I., Repanovici, A., Eds., Eds.; WSEAS Press: Athens, Greece, 2011; pp. 315-318.

58. Pecore, J.L. From Kilpatrick's project method to project-based learning. In International Handbook of Progressive Education; Eryaman, M.Y., Bruce, B.C., Eds.; Peter Lang: New York, NY, USA, 2015; pp. 155-171.

59. Ulrich, C. Invățarea Prin Proiecte. Ghid Pentru Porfesori; Polirom: Iași, Romania, 2016.

60. Ulrich, C. John Dewey and the project-based learning: Landmarks for nowadays Romanian education. J. Educ. Sci. Psychol. 2016, 6, 54-60.

61. Wrigley, S. Avoiding "de-plagiarism": Exploring the affordances of handwriting in the essay-writing process. Act. Learn. High. Educ. 2019, 20, 167-179. [CrossRef]

62. Alzahrani, S.M.; Salim, N.; Abraham, A. Understanding plagiarism linguistic patterns, textual features, and detection methods. IEEE Trans. Syst. Man Cybern. Part C Appl. Rev. 2012, 42, 133-149. [CrossRef]

63. Alzahrani, S.M.; Salim, N.; Palade, V. Uncovering highly obfuscated plagiarism cases using fuzzy semantic-based similarity model. J. King Saud Univ. Comput. Inf. Sci. 2015, 27, 248-268. [CrossRef]

64. Ehsan, N.; Shakery, A. Candidate document retrieval for cross-lingual plagiarism detection using two-level proximity information. Inf. Process. Manag. 2016, 52, 1004-1017. [CrossRef]

65. Franco-Salvador, M.; Gupta, P.; Rosso, P.; Banchs, R.E. Cross-language plagiarism detection over continuous-space and knowledge graph-based representations of language. Knowl. Based Syst. 2016, 111, 87-99. [CrossRef]

66. Klimkowski, T. Influenţe Slave Vechi Asupra Morfologiei şi Sintaxei Limbii Române; Aeternitas: Alba-Iulia, Romania, 2011. 